\title{
Bacterial Degradation of the Saturate Fraction of Arabian Light Crude oil: Biosurfactant Production and the Effect of ZnO Nanoparticles
}

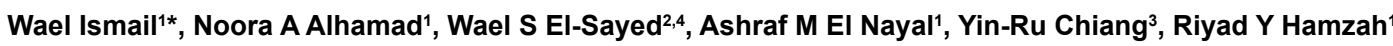 \\ ${ }^{1}$ Biotechnology Program, College of Graduate Studies, Arabian Gulf University, Manama, Kingdom of Bahrain \\ ${ }^{2}$ Taibah University, Faculty of Science, Biology Department, Al-Madinah Al-Monawarah, 344, Kingdom of Saudi Arabia \\ ${ }^{3}$ Biodiversity Research Center, Academia Sinica, Taipei 115, Taiwan \\ ${ }^{4}$ Microbiology Department, Faculty of Science, Ain Shams University, Cairo, Egypt
}

\begin{abstract}
The aim of this research was to study the influence of nanoparticles on the biodegradation of crude oil. Production of biosurfactants was also assessed. Crude oil-utilizing bacteria were isolated from oil fields via enrichment in chemically defined medium with crude oil as a sole carbon source. The isolates could be affiliated to the genera Bacillus, Pseudomonas, Achromobacter, and Microbacterium by $16 \mathrm{~S}$ rRNA gene sequencing and phylogenetic analysis. GC/FID analysis revealed 52 to $98 \%$ degradation of the oil saturate fraction within one month. Nanoparticles of $\mathrm{ZnO}$ inhibited growth and crude oil biodegradation by one isolate (NBHCO4) in a concentration-dependent manner. Growth of the cultures containing $\mathrm{ZnO}$ nanoparticles was relatively slower than that of the nanoparticles-free cultures. Moreover, the oil degradation extent in the nanoparticles-containing cultures (22-50\%) was less than that achieved in cultures lacking ZnO nanoparticles (80\%). Two strains, NBHCO2 and NCEOW, emulsified and utilized water-in-oil emulsions (chocolate mousse). Biosurfactant production in only one crude oil culture (I-19) could be confirmed by the observed reduction in surface tension. Some isolates produced biosurfactants from water-soluble substrates such as glucose. The NBHCO2 strain produced a lipopeptide biosurfactant which reduced the surface tension of the growth medium from 72 to $27 \mathrm{mN} / \mathrm{m}$. A gene of catechol dioxygenase was detected in the I-19, NBHCO4, and NCEOW isolates indicating the potential catabolic capabilities of these strains for degradation of the aromatic oil fraction. In conclusion, metal oxide nanoparticles can interfere with crude oil biodegradation. Biosurfactants are not necessarily a prerequisite for crude oil biodegradation. The isolates can be applied for bioaugmentation of petroleum-polluted soil and biosurfactants production.
\end{abstract}

Keywords: Bioremediation; Biosurfactant; Emulsification; Nanoparticles; Bacillus

\section{Introduction}

Petroleum hydrocarbons are among the most common environmental contaminants [1,2]. Petroleum and its hazardous products can be released into the environment through various production, processing, and consumption operations. Consequently, environmental pollution with petroleum and its products has become an issue of global concern, particularly with the anticipated boost in the production and consumption of fossil fuels [3-5].

Pollution with petroleum hydrocarbons in the Arabian Gulf region has become a serious environmental issue. In deed the Arabian Gulf is one of the most heavily polluted aquatic environments worldwide. It was estimated that ca $60 \%$ of the oil transported via the sea is shipped in the Arabian Gulf [5,6]. Furthermore, the Arabian Gulf region has witnessed the largest oil spill to date in terms of the amount of crude oil discharged. During the 1991 Gulf war the release of about 11 million barrels of crude oil has lead to the pollution of all environmental components in the region [7].

In Kuwait, where the situation was the worst, about $190 \mathrm{~km}$ of border trenches were filled with 3.5 million barrels of crude oil. Moreover, $400 \mathrm{~km}^{2}$ of land were polluted because of the fallout from 800 burning wells which released 50 million $\mathrm{m}^{3}$ of crude oil [8]. The marine environment and ground water reservoirs were also heavily impacted. Another devastating consequence is the formation of more than 300 oil lakes that covered over $49 \mathrm{~km}^{2}$ of land with more than 40 million tons of crude oil $[9,10]$. In addition to land and water pollution with petroleum hydrocarbons, the 1991 Gulf war contributed massively to air pollution [11].
Although more than two decades have elapsed since the catastrophic Gulf war oil spill occurred, the consequences are still apparent today [10]. Following the 1991 Gulf war, some studies have been conducted to evaluate bioremediation as a cleanup technology in the Arabian Gulf territory $[9,12,13]$. Nonetheless, the work achieved to date is not up to the scale of the massive pollution problem. Most of the research done has focused on the marine environment of the Arabian Gulf. In contrast, a few studies have addressed the crude oil-degrading microbial populations in petroleum-impacted soil.

It is well known that one of the factors which often impede the biodegradation of hydrophobic substrates like hydrocarbons and crude oil is their low bioavailability $[14,15]$. This is because these substrates have poor aqueous solubility and therefore, are not readily accessible for microbial attack. To circumvent this problem, microbes, which exist predominantly in the aqueous phase, have evolved different mechanisms to get access to and utilize hydrophobic compounds. Some

*Corresponding author: Wael Ismail, Biotechnology Program, College of Graduate Studies, Arabian Gulf University, Manama, Kingdom of Bahrain, Tel: +97336146948; Fax: +97317239664, E-mail: waelame@agu.edu.bh

Received November 05, 2013; Accepted December 20, 2013; Published December 28, 2013

Citation: Ismail W, Alhamad NA, El-Sayed WS, El Nayal AM, Yin-Ru C, et al (2013) Bacterial Degradation of the Saturate Fraction of Arabian Light Crude oil: Biosurfactant Production and the Effect of ZnO Nanoparticles. J Pet Environ Biotechnol 4: 163. doi:10.4172/2157-7463.1000163

Copyright: $\odot 2013$ Ismail W, et al. This is an open-access article distributed under the terms of the Creative Commons Attribution License, which permits unrestricted use, distribution, and reproduction in any medium, provided the original author and source are credited. 
crude oil-degrading bacteria produce biosurfactants/bioemulsifiers that promote the aqueous solubility, and thus the bioavailability, of petroleum hydrocarbons by solubilization and emulsification $[16,17]$. Consequently, crude oil biodegradation can be enhanced by biosurfactants/bioemulsifiers production. However, this is not always the case because biosurfactants might also negatively impact the biodegradation process [18]. Therefore, further investigations are still needed to better understand biosurfactants production patterns and their role in crude oil biodegradation and action mechanisms. Noteworthy, studies on biosurfactants production by crude oil-degrading bacteria or bacteria inhabiting crude oil-polluted environments in the Arabian Gulf region are very scarce.

The presence of other environmental contaminants such as nanoparticles, can probably have an impact on crude oil biodegradation. Nanoparticles have gained tremendous interest due to their unique physicochemical properties compared to their bulk counterparts [19]. Potential impact of commercial nanoparticles on crude oil biodegradation has not been investigated so far. This is particularly demanding due to the increasing applications of engineered nanoparticles and nanotechnology which will inevitably lead to discharge of nanoparticles into the environment via various routes [19-21]. Accordingly, it is likely that nanoparticles may interfere somehow with the biodegradation of environmental pollutants since some of them are known to have antimicrobial activity [22].

This study was undertaken to isolate crude-oil degrading bacteria from petroleum-polluted soil collected from oil fields in Bahrain and Kuwait and to assess their biodegradation potential. Biosurfactants production by the isolated bacteria was also investigated. Furthermore, we tested the effect of commercially available $\mathrm{ZnO}$ nanoparticles on growth and oil biodegradability.

\section{Materials and Methods}

\section{Chemicals, bacteria, soil, and oil samples}

Chemicals and molecular biology reagents were obtained from Fluka (Switzerland), Sigma (USA) Promega and Qiagen (Germany), and the sterile filters $(0.22$ and $0.45 \mu \mathrm{m})$ were from Millipore (USA). Arab light crude oil was provided by Saudi Aramco (Kingdom of Saudi Arabia) and BAPCO (The Bahrain Petroleum Company). Nanoparticles ( $\mathrm{ZnO}$ nanopowder $<100 \mathrm{~nm}$ ) were purchased from Sigma-Aldrich (Germany). Petroleum-contaminated soil samples were collected from different locations in Bahrain (Awali oil field), and Kuwait (oilimpacted locations including those that date back to the $1991 \mathrm{Gulf}$ War; Al Sabiriya field, and Al Moqawwa field). Moreover, crude oil samples mixed with water (production water) were collected from pipelines. All samples were collected in October 2010 in clean glass containers and kept at room temperature in the laboratory. These samples were used as a source of potential petroleum-degrading microorganisms. The I-19 strain is a Pseudomonas sp. isolated by a MSc student at the Arabian Gulf University [23]. The source of the I-19 strain is crude oilcontaminated soil collected from Al Sabiriya oil field in Kuwait. It was isolated from an enrichment culture in chemically defined medium with biphenyl as a sole carbon source. The I-19 strain could emulsify and grow on crude oil and it is included in the current study to assess its biodegradation potential. Bacillus subtilis DSM 3257 was purchased from Deutsche Sammlung von Mikroorganismen und Zellkulturen (DSMZ, Germany). Genomic DNA from B. subtilis was used as a positive control for detection of the biosurfactants-related genes as described below.

\section{Culture media and growth conditions}

Enrichment of crude oil-degrading-bacteria and the biodegradation experiments (shake-flask cultures) were performed in mineral salts medium containing crude oil as a sole carbon source [24]. Filtersterilized $(0.22 \mu \mathrm{m}$ Stericup filters, Millipore) crude oil was added to sterile mineral salts medium ( 2 or $5 \%, \mathrm{v} / \mathrm{v})$. Biosurfactants production was also tested in $50 \mathrm{ml}$ mineral salts medium containing $10 \mathrm{mM}$ glucose from filter-sterilized stock solution as a sole carbon source. Isolation and purification of the bacteria was done via spread and streak plate techniques on Luria-Bertani (LB) agar. Inocula for the biodegradation experiments were prepared in $50 \mathrm{ml}$ LB-broth (in 100 $\mathrm{ml}$ Erlenmeyer flasks). All liquid cultures were routinely incubated at $30^{\circ} \mathrm{C}$ with shaking at $200 \mathrm{rpm}$. LB-agar plates were incubated at $30^{\circ} \mathrm{C}$ for 48 hours. Growth of bacteria in liquid cultures was monitored by measuring the optical density at $580 \mathrm{~nm}\left(\mathrm{OD}_{580}\right)$ with a Perkin Elmer lambda EZ210 spectrophotometer $(1 \mathrm{~cm}$ optical path).

\section{Enrichment and isolation of bacteria}

Soil samples were suspended in distilled water $(20 \mathrm{~g} / 100 \mathrm{ml})$ and the suspension was shaken for 30 minutes. The soil suspension was then kept at room temperature and allowed to settle and aliquots of the soil slurry $(1 \mathrm{ml})$ were inoculated in $100 \mathrm{ml}$ mineral salts medium (in 250 $\mathrm{ml}$ Erlenmeyer flasks) containing $2 \%$ crude oil as a sole carbon source. Non-sterilized crude oil was used as inoculum in mineral salts medium (10\%) without the addition of soil slurry to check for the presence of bacteria in the oil. Production water was inoculated (2\%) into mineral salts medium containing $2 \%$ filter-sterilized crude oil as a carbon source. Enrichment cultures were incubated for one week. Samples from the various enrichments that showed signs of turbidity, emulsification/ dispersion and/or change in color were serially diluted in sterile saline $(0.9 \% \mathrm{NaCl})$. Aliquots from the culture dilutions $(100 \mu \mathrm{l})$ were spread over LB-agar plates and incubated for 48 hours. Morphologically distinct single colonies from the spread plates were streaked across LBagar plates three times consecutively for purification.

\section{Preparation of inocula for the biodegradation experiments}

To screen the isolated bacteria for crude oil degradation capacity, the various isolates were grown in LB-broth for 16-18 hours. The $\mathrm{OD}_{580}$ of the cultures was then measured and the cells were harvested by centrifugation ( $3500 \mathrm{rpm}, 20$ minutes) at $4^{\circ} \mathrm{C}$. The cell pellet was washed once with basal medium (phosphate buffer $+\mathrm{NH}_{4} \mathrm{Cl}$ ) [24] and the washed cells were resuspended in $5 \mathrm{ml}$ of basal medium. These cell suspensions were used as inocula. All manipulations of the cells were done on ice. Cells were harvested from $2 \mathrm{ml}$ of the cell suspension by centrifugation $\left(14,000 \mathrm{rpm}, 5\right.$ minutes) and heated at $105^{\circ} \mathrm{C}$ for 15 hours in a drying oven for measuring the dry weight.

\section{Crude oil biodegradation assays}

Routinely, $2 \mathrm{ml}$ of each cell suspension (0.04-0.2 gram dry cell weight/l) were inoculated into mineral salts medium containing $2 \%$ crude oil as a sole carbon source and incubated for 4 weeks. Cultures were inspected visually at intervals for turbidity, color change, and oil emulsification/dispersion. Cultures prepared for the growth curve experiments contained 5\% crude oil. In all experiments, crude oil biodegradation was assessed by GC-FID after $n$-hexane extraction from the various cultures as described later. Uninoculated controls were included to monitor sterility and to compensate for abiotic loss of oil. Change in biomass was monitored by measuring the optical density $\left(\mathrm{OD}_{580}\right)$ at hourly intervals during the initial two days of incubation then once weekly. 
Citation: Ismail W, Alhamad NA, El-Sayed WS, El Nayal AM, Yin-Ru C, et al. (2013) Bacterial Degradation of the Saturate Fraction of Arabian Light Crude oil: Biosurfactant Production and the Effect of ZnO Nanoparticles. J Pet Environ Biotechnol 4: 163. doi:10.4172/2157-7463.1000163

Page 3 of 11

\section{Biosurfactants production}

To test selected isolates for biosurfactants production, the bacteria were grown in mineral salts medium with crude oil (2\%) as described earlier. Biosurfactants production was also assessed in cultures growing on water soluble substrates such as glucose $(10 \mathrm{mM})$. Uninoculated medium was included as a control. After different time intervals $(24$ hours and 24 days), samples from the crude oil cultures $(25 \mathrm{ml}$ from the aqueous phase) and the glucose cultures ( $25 \mathrm{ml}$, after 4 days) were withdrawn and the cells were removed by centrifugation for 20 minutes at $3500 \mathrm{rpm}$. The supernatants were then filtered under vacuum through $0.22 \mu \mathrm{m}$ membrane filters to remove residual cells. The surface tension of cell-free culture supernatants was measured with a Kruss K100MK3 tensiometer (Kruss, Germany) equipped with a platinum plate at room temperature via the Wilhelmy plate method [25].

\section{Effect of $\mathrm{ZnO}$ nanoparticles on growth and biodegradation capacity}

This experiment was conducted to assess the impact of commercially available $\mathrm{ZnO}$ nanoparticls on growth and crude oil biodegradation. Nanoparticles of $\mathrm{ZnO}$ were chosen because they are widely applied [26]. The isolate NBHCO4 was cultured in mineral salts medium containing crude oil in the presence of $\mathrm{ZnO}$ nanoparticles. One set of cultures contained $1 \mu \mathrm{g} / \mathrm{ml}$ and another set contained $10 \mu \mathrm{g} /$ $\mathrm{ml}$ of $\mathrm{ZnO}$ nanoparticles. Control cultures without nanoparticles and uninoculated flasks were also included. All cultures were incubated for 28 days at $30^{\circ} \mathrm{C}$. Growth was monitored by measuring the $\mathrm{OD}_{580}$ after time intervals and oil biodegradation was assessed by GC-FID.

\section{Gas Chromatography (GC)}

Gas chromatography was adopted to monitor the degradation of saturated hydrocarbons in the $n$-hexane-soluble fraction. The crude oil from all cultures was extracted once in $n$-hexane. The culture contents were mixed with $15 \mathrm{ml}$ of $n$-hexane by vigorous shaking in a separating funnel for 5 minutes. After the two phases were resolved, the aqueous phase was allowed to drain and the organic phase was collected in clean glass flasks. A portion $(1 \mathrm{ml})$ of the organic phase was then centrifuged at $13,000 \mathrm{rpm}$ for 10 minutes. The supernatant was transferred to a clean Eppendorf tube and diluted 50x in $n$-hexane. Samples $(1 \mu \mathrm{l})$ from all dilutions were injected into an Agilent GC7890A-Markes Headspace System equipped with a FID (flam ionization detector). The column was a HP-5ms (5\%-phenylmethylpolysiloxane, $30 \mathrm{~m} \mathrm{x}$ $0.25 \mathrm{~mm}$ id, $0.25 \mu \mathrm{m}$ film thickness) and the carrier gas helium was used at flow rate of $0.8 \mathrm{ml} / \mathrm{min}$. The injector temperature was $250^{\circ} \mathrm{C}$ and the oven temperature was held at $70^{\circ} \mathrm{C}$ for $2 \mathrm{~min}$ then increased to $300^{\circ} \mathrm{C}$ at $20^{\circ} \mathrm{C} / \mathrm{min}$, thereafter held at $300^{\circ} \mathrm{C}$ for $8.5 \mathrm{~min}$. The peak areas for some components of the $n$-hexane soluble fractions in the GC/FID chromatograms of the different experiments were compared.
The peak area represents the \% of the hydrocarbon constituent in the total amount of the hexane soluble fraction (relative abundance). To assess the extent of oil (hexane soluble fraction) biodegradation, the total area of all the peaks in each GC/FID chromatogram was taken as an indicator.

\section{Polymerase Chain Reaction (PCR)}

Polymerase chain reaction was performed to screen selected isolates for the presence of genes involved in the degradation of aromatic compounds and biosurfactants production. Genomic DNA was isolated from overnight LB-cultures of the different bacteria using the Wizard Genomic DNA Purification kit (Promga, USA) and was used as a template. The primers used are listed in Table 1. The PCR was run on a Biorad DYAD thermocycler (Biorad, USA) and the PCR mixture $(20 \mu \mathrm{l})$ contained $0.2 \mu \mathrm{M}$ from each of the forward and reverse primers, 7-200 ng of genomic DNA, and $2 \mu \mathrm{l}$ of $20 \mathrm{x}$ Taq PCR master mix (Qiagen, Germany). The PCR conditions for each pair of primers were as mentioned in the respective reference.

\section{Amplification, sequencing of 16S rRNA gene and phylogenetic analysis}

A loopful of overnight grown cultures was transferred to $50 \mu \mathrm{l} \mathrm{TE}$ buffer (100 mM Tris-HCl-10 mM EDTA, pH 8.0) and boiled for 5 min. Then resulting cell extract was used as a template for PCR using Platinum Supermix (Invitrogen, USA). The 16S rRNA genes were amplified with eubacterial universal primers (Table 1). PCR mixture consisted of $25 \mu$ Platinum Supermix, $1 \mu$ of each primer (from $10 \mu \mathrm{M}$ stock), $1 \mu \mathrm{l}$ of cell extract, and was adjusted to $50 \mu \mathrm{l}$ with distilled water PCR was performed in Thermal Cycler (Applied Biosystem 2720, USA) and the PCR conditions were adjusted to $5 \mathrm{~min}$ for initial denaturation at $94^{\circ} \mathrm{C}$ followed by 30 cycles of $1 \mathrm{~min}$ at $94^{\circ} \mathrm{C}, 1 \mathrm{~min}$ at $54^{\circ} \mathrm{C}$, and 1 min at $72^{\circ} \mathrm{C}$, and finally $10 \mathrm{~min}$ at $72^{\circ} \mathrm{C}$. The amplicons were subjected to electrophoresis using $1 \%$ agarose gel containing ethidium bromide $(0.05 \%)$ with size marker (DNA ladder, Promega, USA).

Nucleotide sequences of amplified 16S rRNA were determined by automated fluorescent dye terminator sequencing method originally developed by Sanger et al. [32] using DYEynamic ET Terminator Cycle Sequencing Kit (Amersham Pharmacia Biotech) with a model ABI 310 genetic sequence analyzer (Applied Biosystems, CA, USA) according to user manual. Obtained sequences were analyzed by Genetyx-Win MFC application software version 4.0. The reference 16S rRNA gene sequences were retrieved from the GenBank database (National Center for Biotechnology Information NCBI, National Library of Medicine, USA) [33]. Sequences were compared with their closest matches in GenBank with nucleotide-nucleotide BLAST to obtain the nearest phylogenetic neighbors (www.ncbi.nlm.nih.gov/BLAST). Multisequence alignments were performed by Clustal W1.83 XP software and phylogenetic trees were constructed with MEGA (The Biodesign Institute) [34] using evolutionary distance and neighbor-joining method [35].

\begin{tabular}{|c|c|c|c|c|}
\hline Primer name & Primer sequence $5^{\prime}-3^{\prime}$ & Amplified gene or DNA fragment & Expected product size (bp) & Reference \\
\hline $\begin{array}{l}\text { 23cat-f } \\
\text { 23cat-r }\end{array}$ & $\begin{array}{l}\text { CGACCTGATCTCCATGACCGA } \\
\text { TCAGGTCAGCACGGTCA }\end{array}$ & 2,3 catechol dioxygenase & 238 & [27] \\
\hline $\begin{array}{l}\text { sfp0-F } \\
\text { sfp0-R } \\
\text { srfA-F } \\
\text { srfA-R }\end{array}$ & $\begin{array}{c}\text { CTAGAATTCAGATTTACGGAATTTATATG } \\
\text { GGGGAATTCAGGGTGTGCGGCGCATAC } \\
\text { TCCGTTTTTCCTTGTTCACC } \\
\text { TCTTTCTGCCACTGCATCAC }\end{array}$ & $\begin{array}{l}\text { the genes of lipopeptide biosurfactants } \\
\text { from Bacillus subtilis }\end{array}$ & $\begin{array}{l}642 \\
707\end{array}$ & $\begin{array}{l}{[28]} \\
{[28]}\end{array}$ \\
\hline $\begin{array}{l}\text { Kpd1 } \\
\text { Kpd2 }\end{array}$ & $\begin{array}{l}\text { GCCCACGACCAGTTCGAC } \\
\text { CATCCCCCTCCCTATGAC }\end{array}$ & the $r h / B$ gene for rhamnolipid biosynthesis & 226 & [29] \\
\hline $\begin{array}{l}27 \mathrm{~F} \\
1500 \mathrm{R}\end{array}$ & $\begin{array}{l}\text { AGAGTTTGATCCTGGCTCAG } \\
\text { ACGGCTACCTTGTTACGACT }\end{array}$ & The $16 \mathrm{~S}$ rRNA genes & 1500 & $\begin{array}{l}{[30]} \\
{[31]}\end{array}$ \\
\hline
\end{tabular}

Table 1: Primers used in this study. 
Citation: Ismail W, Alhamad NA, El-Sayed WS, El Nayal AM, Yin-Ru C, et al. (2013) Bacterial Degradation of the Saturate Fraction of Arabian Light Crude oil: Biosurfactant Production and the Effect of ZnO Nanoparticles. J Pet Environ Biotechnol 4: 163. doi:10.4172/2157-7463.1000163

Page 4 of 11

\section{Sequence accession numbers}

The 16S rRNA gene sequences obtained in this study have been deposited in GenBank under accession numbers AB824289-AB824294 and $\mathrm{AB} 836753$ to $\mathrm{AB} 836756$

\section{Results}

\section{Isolation and identification of bacteria}

Various enrichment cultures revealed different patterns of color change, turbidity and dispersion of crude oil within one week of incubation. These changes indicated the ability of the organisms in the enrichments to utilize petroleum hydrocarbons as a carbon and energy source. Strong emulsification of the crude oil was also observed in the enrichment which contained only crude oil as an inoculum and carbon source. In total, 10 different bacterial strains could be isolated from the spread plates. Based on the results of the phylogenetic analysis, the isolated bacteria could be affiliated to the genera Bacillus, Pseudomonas, Achromobacter, and Microbacterium (Figure 1, Table 2). The majority of the isolates belong to the Pseudomonas and Bacillus genera. The phylogenetic analysis was based on full 16S rRNA gene sequence for the isolates $\mathrm{NKCO} 2$ and $\mathrm{NKCO} 4$ (isolated from Kuwaiti oil fields), NBHCO3 (isolated from Bahraini oil fields), and NCEOW (isolated from production water), whereas only partial sequence was considered for the remaining isolates (Table 2).

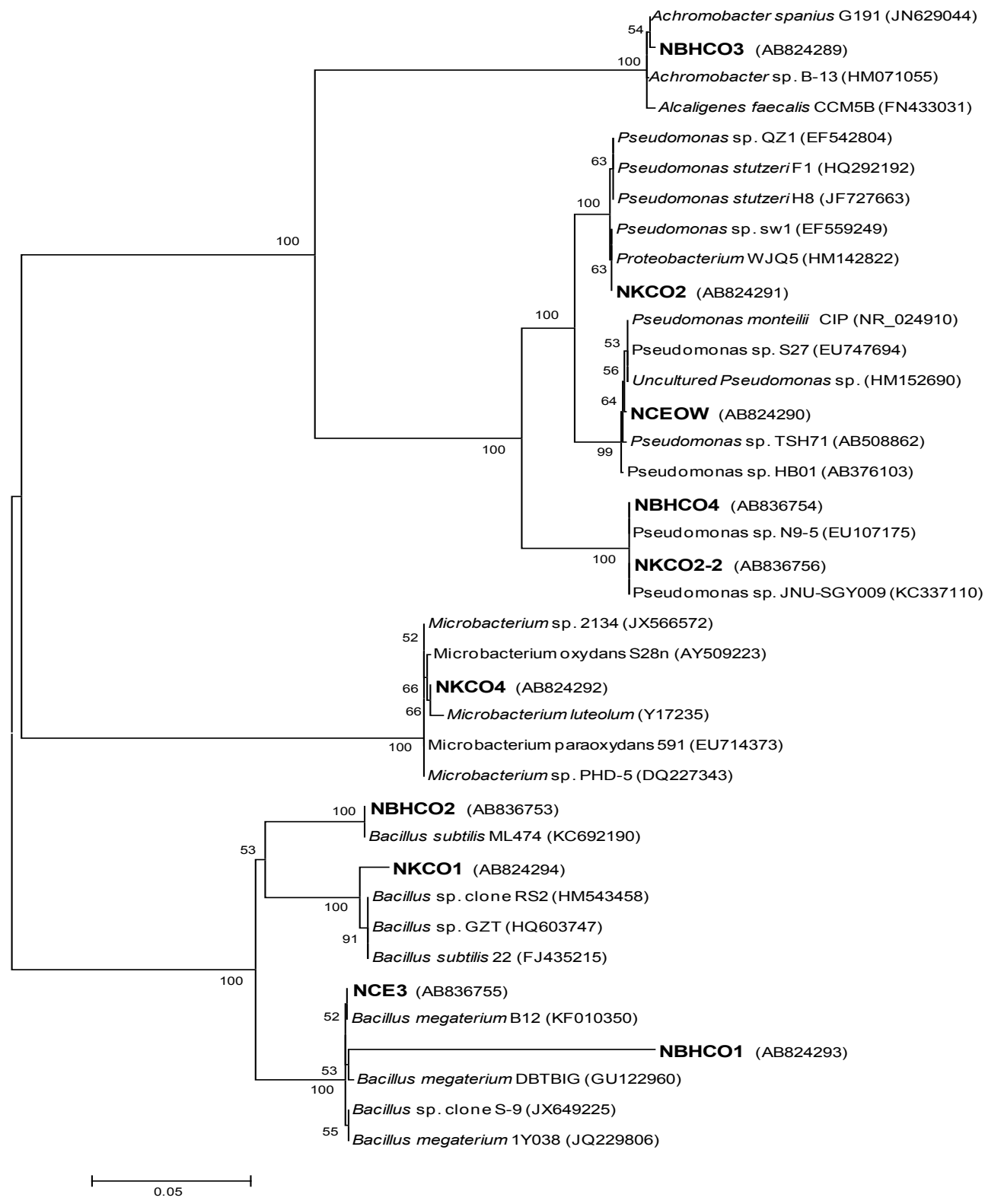

Figure 1: Consensus neighbour-joining phylogenetic tree based on $16 \mathrm{~S}$ rRNA gene sequences showing the phylogenetic positions of isolated strains and related reference taxa. Numbers at nodes indicate bootstrap values of neighbor-joining analysis for 1000 replicates. The scale bar indicates substitutions per nucleotide. The GenBank accession numbers for the 16S rRNA gene sequences are given in parentheses after the strain name. 
Citation: Ismail W, Alhamad NA, El-Sayed WS, El Nayal AM, Yin-Ru C, et al. (2013) Bacterial Degradation of the Saturate Fraction of Arabian Light Crude oil: Biosurfactant Production and the Effect of ZnO Nanoparticles. J Pet Environ Biotechnol 4: 163. doi:10.4172/2157-7463.1000163

Page 5 of 11

\begin{tabular}{|c|c|c|c|c|c|}
\hline Strain & Source & Closest matches & Accession No. ${ }^{a}$ & $\%$ of similarity & Accession No. ${ }^{b}$ \\
\hline NKCO2 & Kuwait, Al Sabiriya Oil Field & Pseudomonas sp. sw1 & EF559249 & 99 & AB824291 \\
\hline $\mathrm{NKCO} 4$ & Kuwait, AI Sabiriya Oil Field & Microbacterium luteolum & Y17235 & 99 & AB824292 \\
\hline NBHCO1 & Bahrain, Awali Oil Field & Bacillus sp. clone S-9 & JX649225 & 98 & AB824293 \\
\hline NKCO1 & Kuwait, Al Sabiriya Oil Field & Bacillus sp. clone RS2 & HM543458 & 99 & AB824294 \\
\hline $\mathrm{NBHCO} 3$ & Bahrain, Awali Oil Field & Achromobacter spanius G191 & JN629044 & 99 & AB824289 \\
\hline NCEOW & Bahrain, Production Water & Pseudomonas sp. TSH71 & AB508862 & 99 & AB824290 \\
\hline NBHCO2 & Bahrain, Awali Oil Field & Bacillus subtilis ML474 & KC692190 & 99 & AB836753 \\
\hline $\mathrm{NBHCO} 4$ & Bahrain, Awali Oil Field & Pseudomonas sp. N9-5 & EU107175 & 99 & AB836754 \\
\hline NCE3 & Crude Oil & Bacillus megaterium B12 & KF010350 & 99 & AB836755 \\
\hline NKCO2-2 & Kuwait, Al Sabiriya Oil Field & Pseudomonas sp. JNU-SGY009 & KC337110 & 99 & AB836756 \\
\hline
\end{tabular}

${ }^{a}$ GeneBank sequence accession numbers of most closely related sequences

${ }^{b}$ GeneBank sequence accession numbers of isolated strain

Table 2: Bacteria isolated from oil fields.

\section{Growth of the isolated bacteria on crude oil}

Growth curves for the isolates NBHCO2 and NBHCO4 (isolated from Bahraini oil fields), NCE3 (isolated from crude oil), NCEOW (isolated from production water), $\mathrm{NKCO} 2-2$ and $\mathrm{NKCO} 1$ (isolated from Kuwaiti oil fields), during the initial 48 hours of incubation are shown in Figure 2. Fluctuations in the $\mathrm{OD}_{580}$ were observed in the NCE3 and NBHCO4 cultures. However, a net increase in turbidity was observed up to 26 hours of incubation. The $\mathrm{OD}_{580}$ then decreased and remained stable. The NBHCO2 culture was the only one which exhibited no fluctuations in the $\mathrm{OD}_{580}$. After a 10 -hour lag phase, the $\mathrm{OD}_{580}$ increased then became constant after 30 hours for 15 hours. The highest $\mathrm{OD}_{580}$ during the first two days was attained in the NBHCO4 and NCE 3 cultures after 26 hours. After 28 days of incubation the $\mathrm{OD}_{580}$ of the NCE3 culture was 1.6 whereas that of the NBHCO4 was 2.4. Fluctuation in culture turbidity was also observed in the NKCO1 culture. An increase in the $\mathrm{OD}_{580}$ of the NKCO1 culture occurred up to 23 hours followed by sudden decrease which lasted for almost 8 hours. After 32 hours of incubation the $\mathrm{OD}_{580}$ increased again and remained almost constant. The culture turbidity of the NKCO2-2 strain increased steadily during the initial 48 hours. After 21 days of incubation the $\mathrm{OD}_{580}$ of the NKCO1 culture reached 5.5 whereas that of the NKCO2-2 was 1.25 . The NCEOW culture turbidity decreased during the initial 6 hours then remained almost constant.

In some oil cultures, water-in-oil emulsions (the so called chocolate mousse) were produced within $24 \sim 72$ hours of incubation. In those cultures no turbidity in the aqueous phase was observed even after prolonged incubation (4 weeks) except the NBHCO2 and NCEOW cultures. In both cultures, the chocolate mousse was dispersed and the aqueous phase became turbid after 3 4 weeks.

\section{Biodegradation of crude oil by selected bacteria}

As shown in Figure 3, the tested bacteria degraded saturated hydrocarbons in the $n$-hexane-soluble fraction of Arabian light crude oil within 28 days of incubation. This was confirmed by the detected decrease in the amounts of the saturate components as compared to uninoculated controls. To estimate the biodegradation extent achieved by the different isolates, the relative amount of the consumed saturate fraction was calculated in comparison with that remaining in the uninoculated controls. The NCE3 strain achieved the highest biodegradation extent (98\%) followed by NBHCO4 (78\%), then NKCO1 (75\%) (Figure 4). Figure 5 displays the change in the relative amount of some saturated hydrocarbons after 28 days of incubation at $30^{\circ} \mathrm{C}$. Both of the NKCO 1 and NBHCO 4 strains reduced the (\%) of $n$-C12 (dodecane), $n$-C13 (tridecane), $n$-C18 (octadecane) and n-C19
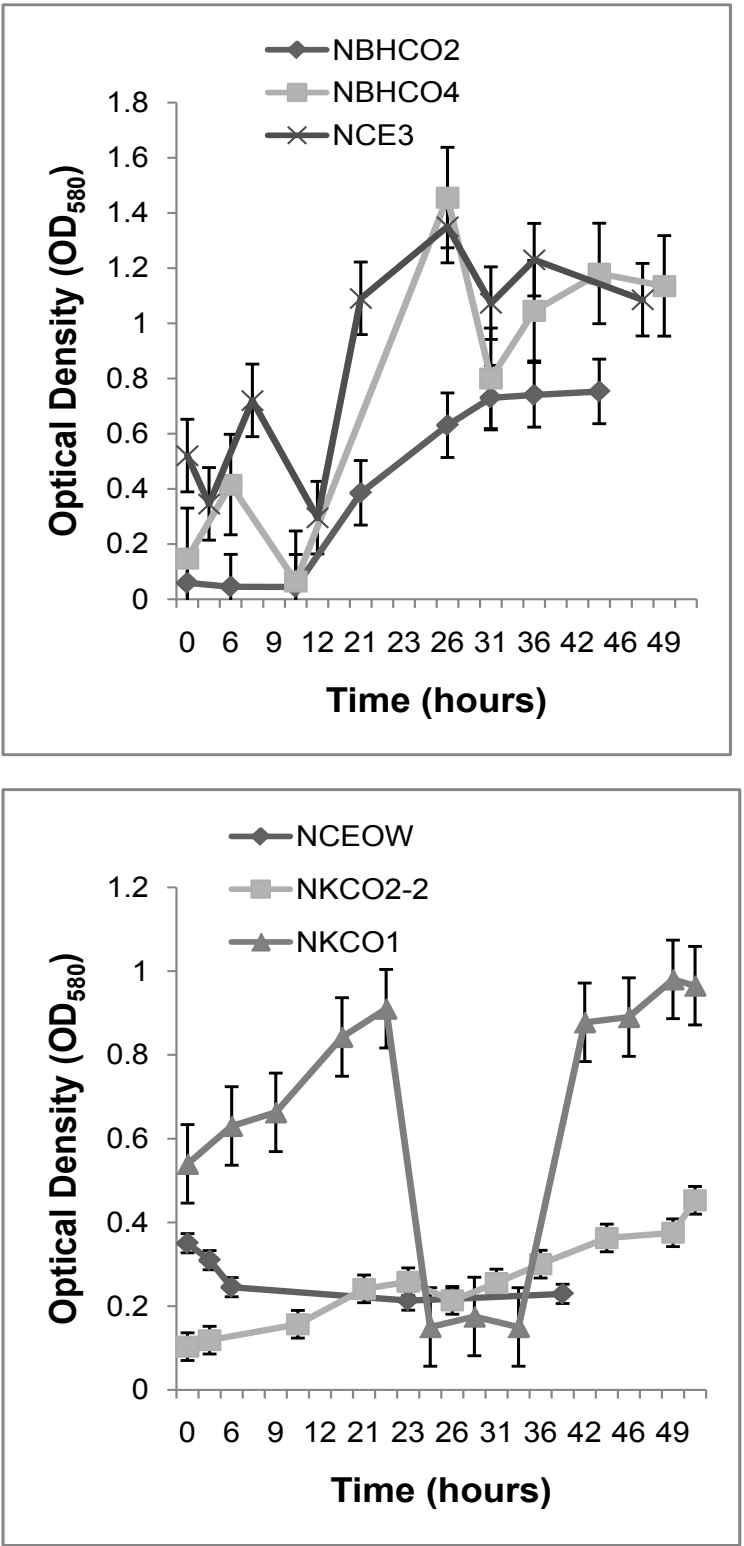

Figure 2: Growth of isolated bacteria in mineral salts medium containing crude oil $(5 \% \mathrm{v} / \mathrm{v})$ at $30^{\circ} \mathrm{C}$ during the initial 48 hours of incubation. Results are means of duplicate measurements from two independent experiments. Error bars represent standard error. 

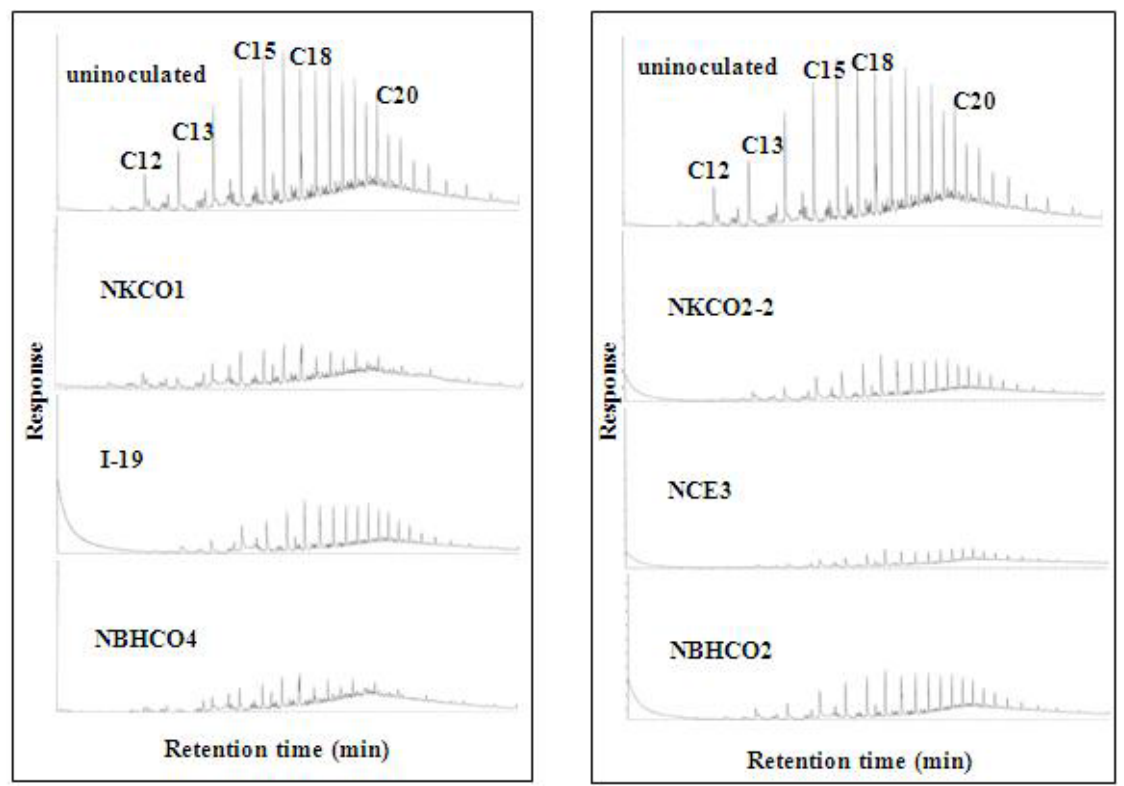

Figure 3: GC/FID chromatograms showing the biodegradation of the hexane-soluble fraction of Arabian light crude oil by some isolates at $30^{\circ} \mathrm{C}$ for 28 days. The tested bacterial isolates are NBHCO2 and NBHCO4 (isolated from Bahraini oil fields), NCE3 (isolated from crude oil), I-19 (isolated from Kuwaiti oil field), NKCO-2-2 and NKCO1 (isolated from Kuwaiti oil fields).

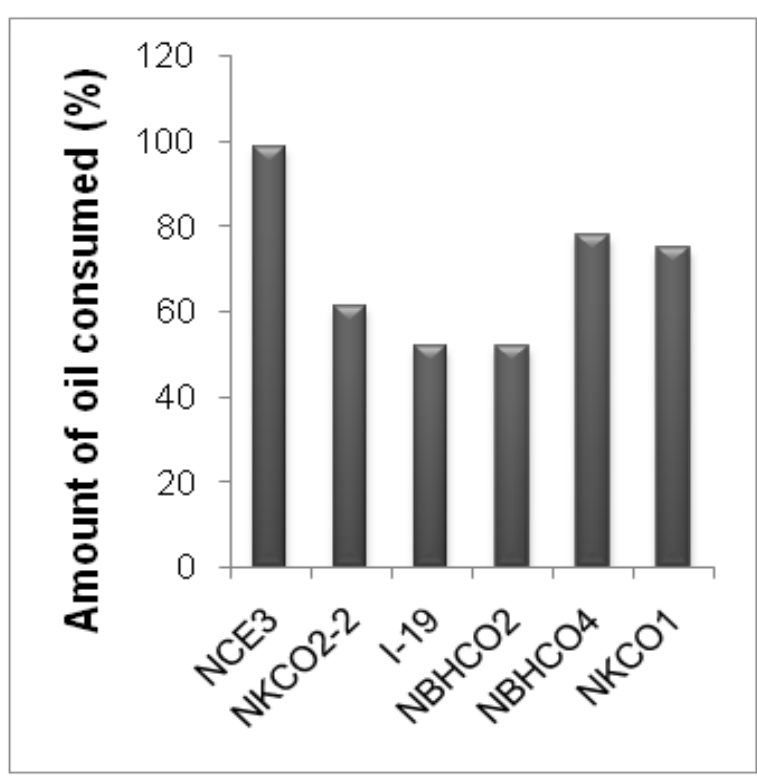

Figure 4: Amount of oil (\%, hexane-soluble fraction) consumed after biodegradation of crude oil by the isolated bacteria at $30^{\circ} \mathrm{C}$ for 28 days.

(nonadecane) hydrocarbons. The other tested isolates (I-19, NCE3, NKCO2-2) drastically reduced the $n$-C12 hydrocarbons $\%$ as compared to the uninoculated control. However, little increase in the $n$-C12\% was observed in the NBHCO2 culture. The NCE3, NBHCO2, I-19 and NKCO2-2 isolates also reduced hydrocarbons in the range $n$-C13 and $n$-C18. The largest \% reduction was achieved by the NCE3 strain. The degradation preference changed with the $n$-C15 (pentadecane) and $n$-C20 (eicosane) hydrocarbons. A relative increase in the $\%$ of the $n$-C15 constituents was observed in the NBHCO2, I-19 and NKCO22 cultures. On the contrary, the NCE3 strain achieved almost $50 \%$ reduction in the relative proportion of $n$-C15 hydrocarbons. The $\%$ proportion of the $n$-C20 hydrocarbons did not reveal significant change in most cultures. Exceptionally, the NCE3 strain caused ca 35\% increase in the $n$-C20 hydrocarbon relative amount.

\section{Effect of $\mathrm{ZnO}$ nanoparticles on growth and crude oil biodegradation}

The $\mathrm{ZnO}$ nanoparticles were added to the NBHCO4 culture $(1 \mu \mathrm{g} / \mathrm{ml}$ and $10 \mu \mathrm{g} / \mathrm{ml}$ ) to test their effect on bacterial growth and oil biodegradation. The NBHCO4 strain grew in crude oil cultures containing $\mathrm{ZnO}$ nanoparticles within 28 days at $30^{\circ} \mathrm{C}$. The color of the cultures turned brownish and the oil got dispersed. No apparent differences in color or oil dispersion pattern were observed between cultures having and those lacking nanoparticles. However, the growth of the nanoparticles-containing cultures was slower than that of the cultures containing no nanoparticles. The maximum $\mathrm{OD}_{580}$ was higher in the culture containing nanoparticles at $1 \mu \mathrm{g} / \mathrm{ml}$ (Figure 6).

The GC/FID chromatograms (Figure 7) revealed degradation of the hexane-soluble oil fraction in the nanoparticles-containing cultures. Interestingly, the amount of oil consumed by NBHCO4 was much less in nanoparticles-containing cultures. Cultures containing 1 and $10 \mu \mathrm{g} /$ $\mathrm{ml}$ of $\mathrm{ZnO}$ nanoparticles consumed 50 and $22 \%$ of the hexane-soluble fraction, respectively, after 28 days of incubation. The nanoparticlesfree culture consumed $80 \%$ of the hexane soluble fraction.

\section{Biosurfactants production by the isolated bacteria}

Dispersion/emulsification of crude oil in the growth medium by most of the tested bacteria occurred within the initial 2-3 days of incubation. In some cultures such as I-19, NBHCO4, and NCE3, oil dispersion was observed even a few hours after inoculation. The strongest dispersion occurred in the I-19 and NBHCO4 cultures. The cultures revealed different sizes of the oil droplets. These data indicate the presence of some sort of tensioactive agents (biosurfactants/ bioemulsifiers) in the crude oil cultures. There was no significant 

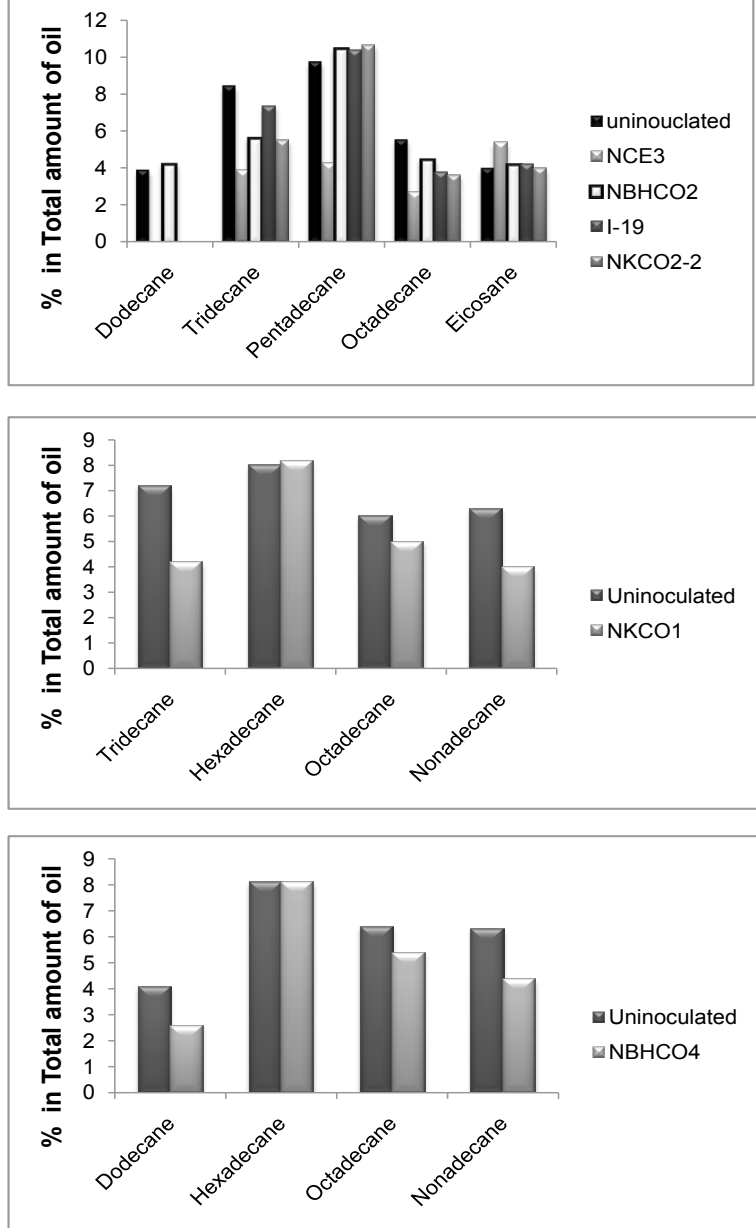

Figure 5: Changes in the relative proportions of hydrocarbon components in the hexane-soluble fraction of Arabian light crude oil after biodegradation by the isolated bacteria for 28 days at $30^{\circ} \mathrm{C}$.

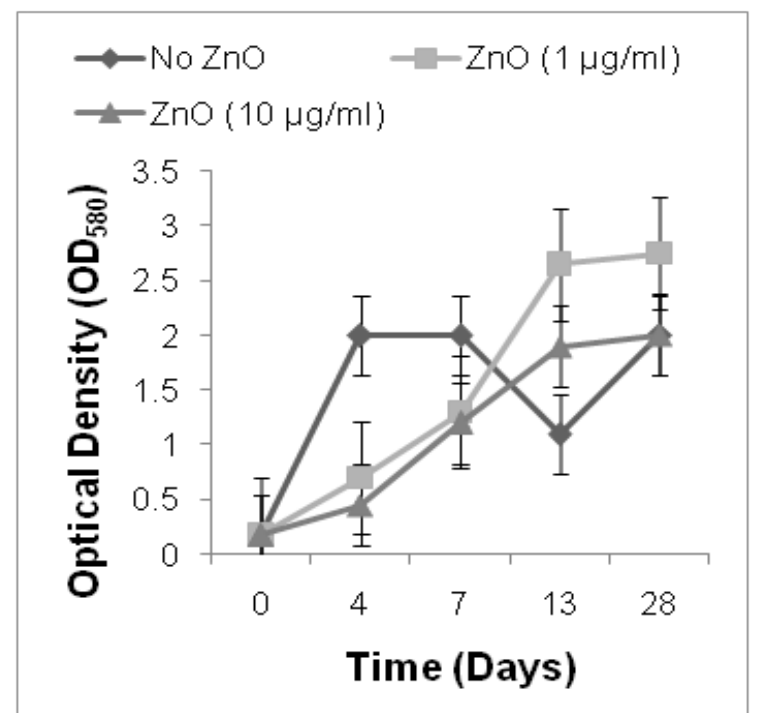

Figure 6: Growth of the NBHCO4 strain in mineral salts medium containing crude oil $(5 \% \mathrm{v} / \mathrm{v})$ at $30^{\circ} \mathrm{C}$ in the presence or absence of $\mathrm{ZnO}$ nanoparticles.

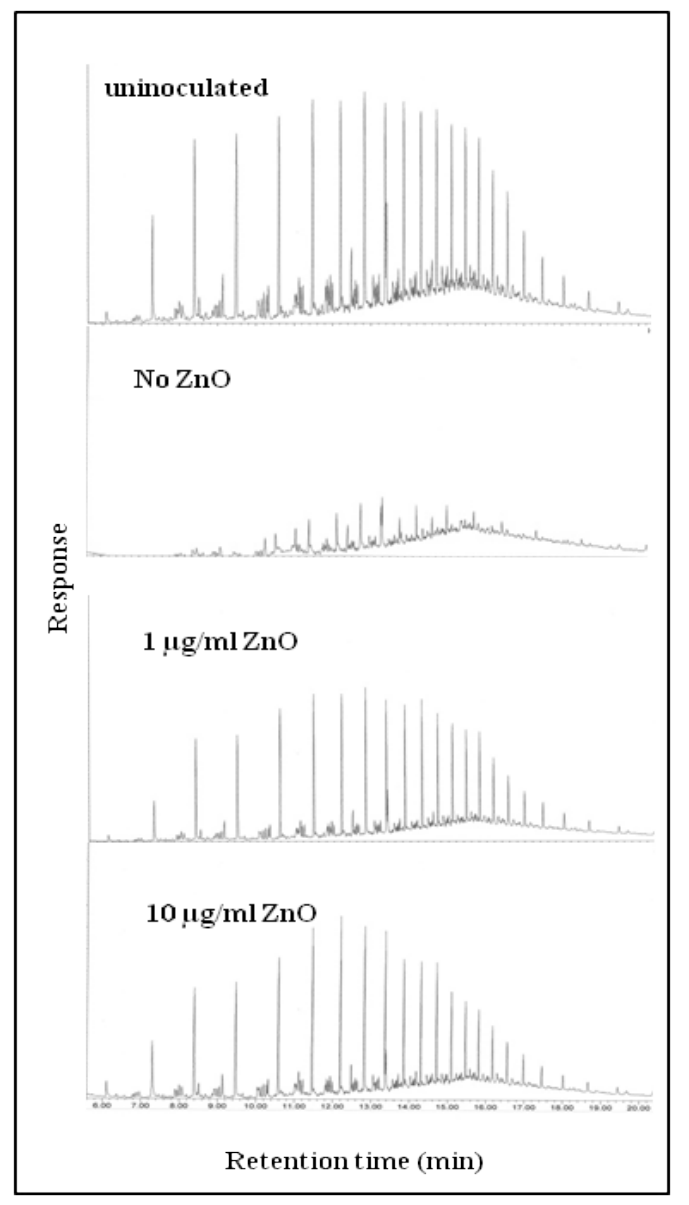

Figure 7: GC/FID chromatograms showing the influence of $\mathrm{ZnO}$ nanoparticles on the biodegradation of the hexane-soluble fraction of Arabian light crude oil by the NBHCO 4 isolate at $30^{\circ} \mathrm{C}$ for 28 days.

difference in surface tension between most of the crude oil cultures and the uninoculated medium (Figure 8). After 24 hours of incubation, the lowest surface tension was measured in the NKCO1 culture (54 $\mathrm{mN} / \mathrm{m})$. However, after 24 days, the surface tension in the I- 19 culture decreased from 59.5 (after 24 hours) to 52.7 to record the lowest surface tension among the tested cultures. After two weeks of incubation, most of the oil droplets in the I-19 and NCEOW cultures coalesced. The tested bacteria produced biosurfactants using glucose as a sole carbon source. This was confirmed by measurement of surface tension (Figure 8). The differences in surface tension between the cultures and the uninoculated medium were much larger than those observed in the crude oil cultures. The lowest surface tension was measured in the NBHCO2 glucose culture $(27 \mathrm{mN} / \mathrm{m})$ after 4 days of incubation.

Detection of genes involved in aromatic hydrocarbons biodegradation and biosurfactants production

Gene of 2,3-catechol dioxygenase was detected only in NBHCO4, I-19, NCEOW. Genes of lipopeptide biosurfactants biosynthesis in Bacillus subtilis were detected only in the NBHCO2 strain (Figure 9). A rhamnosyl transferase-encoding gene involved in biosynthesis of rhamnolipids biosurfactants in Pseudomonas aeruginosa could not be detected in any of the tested isolates. 
Citation: Ismail W, Alhamad NA, El-Sayed WS, El Nayal AM, Yin-Ru C, et al. (2013) Bacterial Degradation of the Saturate Fraction of Arabian Light Crude oil: Biosurfactant Production and the Effect of ZnO Nanoparticles. J Pet Environ Biotechnol 4: 163. doi:10.4172/2157-7463.1000163

Page 8 of 11

\section{Discussion}

As shown by phylogenetic analysis, the majority of the isolated bacteria belong to Bacillus and Pseudomonas genera. Literature search revealed that various species of Pseudomonas and Bacillus are common inhabitants of petroleum-polluted ecosystems. Furthermore, these organisms are well known for their capacity to degrade a range of petroleum hydrocarbons [36-38]. In contrast Achromobacter and Microbacterium spp. have been much less frequently isolated from crude oil-polluted niches $[39,40]$. This also agrees with the results of the phylogenetic analysis reported in this study. In the Arabian Gulf region, hydrocarbon-utilizing Microbacterium spp. were isolated from legume leaves [41] and along the Arabian Gulf coast [42,43]. Recently, Tanase et al. [44] isolated hydrocarbon-degrading Achromobacter xylosoxidans from oil-polluted soil. Also in line with our results, Minf et al. [16] isolated hydrocarbon-degrading Achromobacter sp. from Tunisian oil fields. To our knowledge, crude oil-degrading and emulsifying Achromobacter and Microbacterium species have not been reported before as isolates from oil-polluted soil in Kuwait.

Changes in culture turbidity, color, and oil dispersion/emulsification indicate the ability of the tested isolates to utilize petroleum hydrocarbons for growth and energy production. The fluctuation of

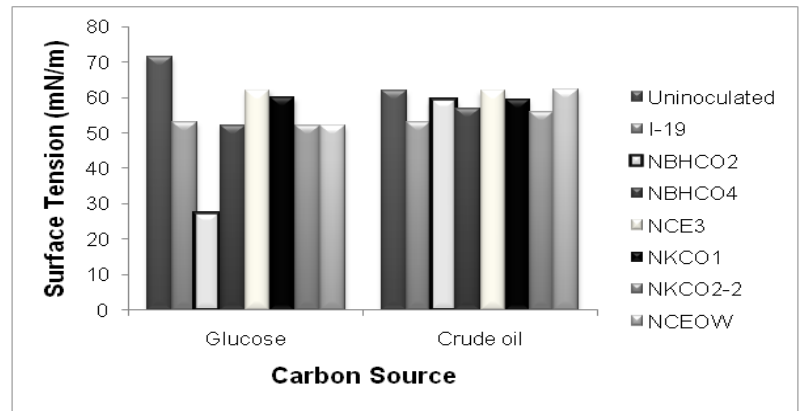

Figure 8: Change in surface tension of cell-free culture supernatants. Bacteria were grown at $30^{\circ} \mathrm{C}$ in mineral salts medium containing either glucose $(10 \mathrm{mM})$ or crude oil $(2 \%, \mathrm{v} / \mathrm{v})$. the $\mathrm{OD}_{580}$ in most of the cultures during the initial two days could be attributed to attachment and detachment of the bacterial cells to and from the oil droplets. Bacterial adhesion to hydrocarbons is one strategy by which hydrocarbonoclastic bacteria overcome the extremely low aqueous solubility of hydrocarbons [45]. Similar results were reported by Bredholt et al. [46]. Moreover, Obuekwe et al. [47] investigated hydrocarbon degradation as a function of cell surface hydrophobicity and found that higher degradation extent is correlated with higher cell-surface hydrophobicity. Another plausible reason for the observed fluctuations in culture density could be the structural complexity and heterogeneous nature of the crude oil. Different types of interactions between the cells and the myriad of compounds in crude oil make the biodegradation process very dynamic. Petroleum hydrocarbons differ in their toxicity, accessibility, and recalcitrance. The turbidity profile of the NKCO1 culture mimics a diauxic growth curve. Transient decline in the turbidity of the NKCO1which remained for several hours could be due to growth inhibition by toxic oil components or oxygen deficiency. The recovery from this temporary stationary phase resulted in increase in culture turbidity again. However, other factors like the attachment to /detachment from the oil droplets may be involved.

The isolated bacteria caused substantial degradation of the hexanesoluble (saturate) fraction of Arabian light crude oil within one month. Accordingly, these bacteria possess the catabolic machinery that enables them to utilize various aliphatic hydrocarbons of crude oil. This is common among bacteria isolated from crude oil-impacted ecosystems [44,48]. However the tested bacterial isolates achieved different degradation extents. Crude oil-utilizing microorganisms differ in their degradation capacities $[47,49]$. Although we do not have a direct evidence for the degradation of the aromatic fraction, the presence of a gene of catechol dioxygenase in some isolates suggests the ability of these bacteria to utilize aromatic substrates. Differences in biodegradation extent may be attributed to various factors such as cell surface hydrophobicity, enzyme activity and specificity, genes arrangement and regulation of gene expression, as well as biosurfactants/bioemulsifiers production. The highest degradation extent was recorded for NCE3 and NBHCO4. These two strains are among the isolates that caused strong dispersion of crude oil in the culture medium. This could be a reason for their higher biodegradation capacities [17].
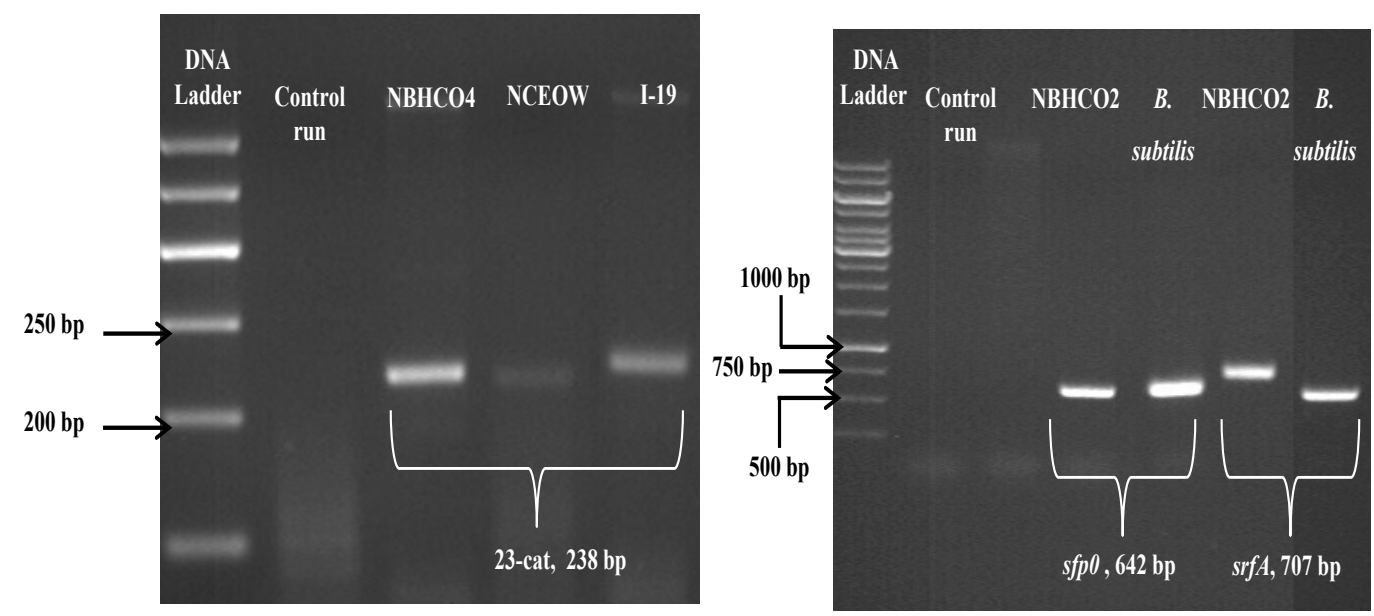

Figure 9: Images of agarose gels showing results of PCR for the detection of genes related to lipopeptide biosurfactants production (sfp 0 and srfA) and catechol dioxygenase in some isolates. Genomic DNA isolated from different bacteria was used as a template. Genomic DNA from B. subtilis was used a positive control for the $s f p 0$ and srfA genes. Control runs are PCR runs without template DNA. 
It is worth mentioning that stronger oil dispersion does not always correlate with enhanced biodegradation efficiency [50]. The stability (decay constant) of the crude oil emulsion is another important factor. In line with this, NKCO1, which caused slight dispersion of the oil, achieved degradation extent comparable to that achieved by the stronger emulsifier NBHCO4. Interestingly, although the NCE3 isolate achieved degradation extent higher than that achieved by the NKCO1 strain, the NKCO1 culture reached $\mathrm{OD}_{580}$ more than 3 fold (5.5) higher than that of the NCE3 culture (1.6) after 3 weeks of incubation. It can be proposed that the NKCO1 strain utilized hydrocarbons from the other fractions such as aromatics, asphaltenes and resins and attained higher $\mathrm{OD}_{580}$. Another explanation for this observation is that NKCO1 can achieve complete degradation of the hydrocarbons whereas NCE3 can only affect partial or incomplete degradation. This also might explain why the NKCO1 culture attained much higher biomass yield than that of the NBHCO4 culture although both achieved similar degradation extents for the saturate fraction. However, this needs further investigations.

The changes observed in the relative proportions of the various aliphatic hydrocarbons indicated that the tested bacteria did not utilize them equally. Preferential degradation of hydrocarbons by various bacteria has been reported by many authors [51,52]. The differential degradation of hydrocarbons could be due to toxicity and recalcitrance effects. Petroleum hydrocarbons are usually degraded in the following order $n$-alkanes $>$ cycloalkanes and branched alkanes $>$ aromatic hydrocarbons $>$ resins and asphaltenes [51,53]. The differential utilization of the aliphatic hydrocarbons in the $n$-hexane-soluble fractions may reflect the different degradation extents.

The isolated bacteria appear not to be capable of utilizing the $n$-C16 and $n$-C20 hydrocarbons because no significant changes could be observed in the relative amounts of these compounds. The observed increase in the $n$-C20 hydrocarbons in the NCE3 culture can be attributed to recalcitrance or biotransformation of long-chain alkanes to $n$-C20. The same might apply for the observed increase in the $n$-C15 alkanes in the NBHCO2, I-19, and NKCO2-2 cultures. The reduction in the relative amounts of the $n$-C12, $n$-C13, and $n$-C18 hydrocarbons indicates utilization of the compounds by the tested bacterial isolates. The results reported by some authors are in a good agreement with the results reported here. Recently, Wang et al. [48] studied the degradation of crude oil by a novel Dietzia strain isolated from a deep oil reservoir. After 5 days of cultivation on crude oil, they observed a decrease in hydrocarbons with the chain length $\leq n-\mathrm{C} 25$ and increase in the relative abundance of the $\geq n$-C28 hydrocarbons. After 22 days of incubations, the ratios of $\leq n$ - $\mathrm{C} 22$ and $\geq n$-C28 hydrocarbons decreased and there was an accumulation of hydrocarbons ranging from $n$-C23 to $n$-C27.

Palittapongarnpim et al. [54] reported that degradation of crude oil by some yeasts revealed decrease in the amount of long chain alkanes and accumulation of short chain fractions around $n$-C10. They explained these results by assuming that the long chain alkanes are degraded and transformed to short chain ones. Biosurfactants/ bioemulsifiers interact variably with different hydrocarbons $[48,55]$. This differential behavior should preferentially enhance the aqueous solubility of certain hydrocarbons and consequently, promote their degradation over the less bio-available compounds.

Nanoparticles are gaining increasing interest due to their unique physicochemical properties and potential applications in the environmental and biological fields [19]. Very few studies have addressed the impact of nanoparticles on bioremediation and biodegradation of environmental pollutants. In this study, $\mathrm{ZnO}$ nanoparticles were chosen to test their effect on the growth of
NBHCO4 and crude oil biodegradation. The results showed a negative impact of $\mathrm{ZnO}$ nanoparticles on the growth and crude oil degradation extent. The slower growth and lower degradation percentages of the $\mathrm{ZnO}$-containing culture is probably due to some sort of inhibitory effect of $\mathrm{ZnO}$ nanoparticles. The observation that the effect of $\mathrm{ZnO}$ nanoparticles on the NBHCO4 culture was concentration-dependent further corroborates the inhibitory action. Some types of nanoparticles including $\mathrm{ZnO}$, exhibit antimicrobial activity against several bacteria [22]. Recently, Tilston et al. [56] reported that nanoscale zerovalent iron inhibited microbial degradation of chloroaromatic compounds in soil. In contrast $\mathrm{Fe} / \mathrm{Ni}$ nanoparticles promoted the biodegradation of phenol [57]. Obviously, the effect of nanoparticles on the biological degradation of environmental contaminants awaits further investigations.

Dispersion/emulsification of crude oil in the culture medium suggests the presence of tensioactive agents. Production of biosurfactants is known amongst crude oil and hydrocarbon-degrading bacteria $[14,16]$. This is another way by which hydrocarbonoclastic microbes circumvent the hydrophobicity and low aqueous solubility of the hydrocarbon substrates. In contrast to the proposed bacterial adherence to the oil droplets which was inferred from the observed fluctuations in culture density, the production of biosurfactants was confirmed by the observed reduction in surface tension in the I-19 crude oil culture. For the other crude oil cultures, the extent of surface tension reduction, as compared to the uninoculated control, was so small to conclude biosurfactants production. Probably, crude oil inhibited biosurfactants production or the tensioactive agent may be a bioemulsifier-type biosurfactant [58]. Alternatively, the bacterial cells themselves can act as biosurfactants/bioemulsifiers [59] or the produced biosurfactants are not excreted to the extracellular medium. This could be corroborated by the fact that the surface tension measurements were performed in cell-free culture supernatants. Moreover, dispersion of crude oil in most of the cultures was observed a few hours after the incubation. It is also worth mentioning that the presence of oils in the growth medium usually interferes with surface tension measurements [25]. Finally, the role of biosurfactants in biodegradation of hydrophobic compounds is still controversial [14].

The large reduction in surface tension observed in most of the glucose cultures may be due to biosurfactants that are qualitatively and/or quantitatively different from those produced in the crude oil cultures. Nayak et al. [60] reported that an efficient biosurfactant reduces the surface tension of the culture medium by more than 20 $\mathrm{mN} / \mathrm{m}$. This agrees with the surface tension measurements performed in the NBHCO2, I-19, NBHCO4, NBHCO2, NKCO2-2, and NCEOW cultures. The disability of these bacteria to reduce the surface tension in the crude oil cultures, similar to what they did in the glucose cultures, suggests that biosurfactants production might be prohibited. The carbon source is a significant determinant of the type, yield, and activity of the produced biosurfactants [61]. Glucose is widely used for biosurfactant production by many bacteria $[61,62]$. The biosurfactant produced by the NBHCO2 strain is a lipopeptide as confirmed by the detection of the relevant genes. Neither genes of lipopeptide nor those of rhamnolipid biosurfactants production could be detected in the other tested bacteria. This suggests that these bacteria may produce other types of biosurfactants/bioemulsifiers.

The absence of turbidity in most of the cultures containing waterin-oil emulsions (chocolate mousse) shows the inability of the tested bacteria to utilize these emulsions. Water-in-oil emulsions are known to be microbiologically recalcitrant [63]. This explains why most of the tested bacteria could not grow on them. Interestingly, two of the 
Citation: Ismail W, Alhamad NA, El-Sayed WS, El Nayal AM, Yin-Ru C, et al. (2013) Bacterial Degradation of the Saturate Fraction of Arabian Light Crude oil: Biosurfactant Production and the Effect of ZnO Nanoparticles. J Pet Environ Biotechnol 4: 163. doi:10.4172/2157-7463.1000163

isolated bacteria, $\mathrm{NBHCO} 2$ and $\mathrm{NCEOW}$, transformed chocolate mousse into oil-in-water emulsions after prolonged incubation. This was concomitant with the appearance of turbidity in cultures of these two isolates. It can be concluded that both of these isolates are able to emulsify chocolate mousse and utilize the resulting oil-in-water emulsions after prolonged incubation. Similar results were reported for Pseudomonas sp. and Rhodococcus sp. [46,64].

\section{Conclusions}

From the results it can be concluded that oilfields in Kuwait and Bahrain represent a good source of petroleum-degrading bacteria. The multiple phenotypes (crude oil degradation and biosurfactants production) of the isolated bacteria make them promising for bioaugmentation of petroleum-polluted soil in the Arabian Gulf region as well as biosurfactant production. We showed that commercially available $\mathrm{ZnO}$ nanoparticles can interfere with the biodegradation process. However, it is important to conduct in-depth investigations of the impact of nanoparticles on the growth and biodegradation capacity of environmental microorganisms. Biodegradation of crude oil by some bacteria may occur without production of biosurfactants. However, the role of biosurfactants, in the bioremediation/biodegradation processes needs further investigations.

\section{Acknowledgements}

The authors gratefully acknowledge the financial support by the Arabian Gulf University. We also thank Kuhnikrishnan Thottathan and Nada Obaid (General Directorate of Forensic Science Evidence-Public Prosecution-Kingdom of Bahrain) for technical support with the GC analysis.

\section{References}

1. Philp CJ, Bamforth SM, Singleton I, Atlas RM (2005) Environmental pollution and restoration: A role for bioremediation. Washington DC, ASM Press 1-48.

2. Margesin R, Moertelmaier C, Mair J (2013) Low-temperature biodegradation of petroleum hydrocarbons ( $n$-alkanes, phenol, anthracene, pyrene) by four actinobacterial strains. Int Biodeter Biodegr 84: 185-191.

3. http://www.iea.org/publications/freepublications/publication/fs GlobalEnergyTrends.pdf

4. Dehghani A, Sattarin M, Bridjanian H, Mohamadbeigy KH (2009) Investigation on effectiveness parameters in residue upgrading method. Petroleum and Coal 51: 229-23.

5. Mahmoud HM, Al-Hasan RH, Sorkhoh NA, Eliyas M, Radwan SS (2009) Attenuation of oil pollutants in the Arabian Gulf water by bacteria naturally associated with live fish. Int Biodeter Biodegr 63: 615-620.

6. Vazquez MA, Allen KW, Kattan YM (2000) Long-Term Effects of the 1991 Gulf War on the Hydrocarbon Levels in Clams at Selected Areas of the Saudi Arabian Gulf Coastline. Mar Pollut Bull 40: 440-448.

7. Michel J (2011) 1991 Gulf war oil spill. Fingas M (ed), Oil Spill Science and Technology. Elsevier, USA, p. 1127-1132.

8. Vandecasteele JP (2008) Petroleum Microbiology: Concepts, Environmental Implications, Industrial Applications. Editions Technip France.

9. Balba MT, Al-Daher R, Al-Awadhi N, Chino H, Tsuji H (1998) Bioremediation of oil-contaminated desert soil: The Kuwaiti experience. Environ Int 24: 163-173.

10. Alfailakawi A (2013) Monitoring changes and their causes in places with hydrocarbon pollution in the State of Kuwait using remote sensing and geographic information system techniques. Arabian Gulf University, Kingdom of Bahrain.

11. Ahmed MH, El-Raey M, Nasr SM, Frihy OE (1998) Socioeconomic impact of pollution on ecosystems of the Arabian Gulf. Environ Int 24: 229-237.

12. Al-Bader D, Eliyas M, Rayan R, Radwan S (2013) Subsurface associations of Acaryochloris-related picocyanobacteria with oil-utilizing bacteria in the Arabian Gulf water body: promising consortia in oil sediment bioremediation. Microb Ecol 65: 555-565.
13. Al-Mailem DM, Eliyas M, Radwan SS (2013) Oil-bioremediation potential of two hydrocarbonoclastic, diazotrophic Marinobacter strains from hypersaline areas along the Arabian Gulf coasts. Extremophiles 17: 463-470.

14. Ward OP (2010) Microbial biosurfactants and biodegradation. Adv Exp Med Biol 672: 65-74.

15. Franzetti A, Tamburini E, Banat IM (2010) Applications of biological surface active compounds in remediation technologies. Adv Exp Med Biol 672: 121134

16. Mnif S, Chamkha M, Labat M, Sayadi S (2011) Simultaneous hydrocarbon biodegradation and biosurfactant production by oilfield-selected bacteria. J Appl Microbiol 111: 525-536.

17. Chen $Q$, Bao M, Fan X, Liang S, Sun $P$ (2013) Rhamnolipids enhance marine oil spill bioremediation in laboratory system. Mar Pollut Bull 71: 269-275.

18. Mohanty S, Mukherji S (2013) Surfactant aided biodegradation of NAPLs by Burkholderia multivorans: comparison between Triton X-100 and rhamnolipid JBR-515. Colloids Surf B Biointerfaces 102: 644-652.

19. Liu WT (2006) Nanoparticles and their biological and environmental applications. J Biosci Bioeng 102: 1-7.

20. Fabrega J, Luoma SN, Tyler CR, Galloway TS, Lead JR (2011) Silver nanoparticles: behaviour and effects in the aquatic environment. Environ In 37: 517-531.

21. Navarro E, Baun A, Behra R, Hartmann NB, Filser J, et al. (2008) Environmenta behavior and ecotoxicity of engineered nanoparticles to algae, plants, and fungi. Ecotoxicology 17: 372-386.

22. Azam A, Ahmed AS, Oves M, Khan MS, Habib SS, et al. (2012) Antimicrobial activity of metal oxide nanoparticles against Gram-positive and Gram-negative bacteria: a comparative study. Int J Nanomedicine 7: 6003-6009.

23. Rowaihi AS (2012) Isolation and characterization of biosurfactants-producing microorganisms. Arabian Gulf University, Kingdom of Bahrain Bahrain.

24. Mohamed Mel-S, Ismail W, Heider J, Fuchs G (2002) Aerobic metabolism of phenylacetic acids in Azoarcus evansii. Arch Microbiol 178: 180-192.

25. Walter V, Syldatk C, Hausmann R (2010) Screening concepts for the isolation of biosurfactant producing microorganisms. Adv Exp Med Biol 672: 1-13.

26. Chen P, Powell BA, Mortimer M, Ke PC (2012) Adaptive interactions between zinc oxide nanoparticles and Chlorella sp. Environ Sci Technol 46: 12178-12185.

27. Baek KH, Yoon BD, Cho DH, Kim BH, Oh HM, et al. (2009) Monitoring bacteria population dynamics using real-time PCR during the bioremediation of crudeoil-contaminated soil. J Microbiol Biotechnol 19: 339-345

28. Sekhon KK, Khanna S, Cameotra SS (2011) Enhanced biosurfactant production through cloning of three genes and role of esterase in biosurfactant release. Microb Cell Fact 10: 49.

29. Bodour AA, Drees KP, Maier RM (2003) Distribution of biosurfactant-producing bacteria in undisturbed and contaminated arid Southwestern soils. Appl Environ Microbiol 69: 3280-3287.

30. Stackebrandt E, Goodfellow M (1991) Nucleic acid techniques in bacterial systematics. Wiley USA.

31. Massol-DeyaAA, Odelson DA, Hickey RF, Tiedje JM (1995) Bacterial community fingerprinting of amplified $16 \mathrm{~S}$ and 16-23S ribosomal DNA gene sequences and restriction endonuclease analysis (ARDRA). Molecular Microbial Ecology Manual 289-296.

32. Sanger F, Nicklen S, Coulson AR (1977) DNA sequencing with chain-terminating inhibitors. Proc Natl Acad Sci U S A 74: 5463-5467.

33. Altschul SF, Madden TL, Schäffer AA, Zhang J, Zhang Z, et al. (1997) Gapped BLAST and PSI-BLAST: a new generation of protein database search programs. Nucleic Acids Res 25: 3389-3402.

34. Kumar S, Tamura K, Nei M (2004) MEGA3: Integrated software for Molecular Evolutionary Genetics Analysis and sequence alignment. Brief Bioinform 5: 150-163.

35. Saitou N, Nei M (1987) The neighbor-joining method: a new method for reconstructing phylogenetic trees. Mol Biol Evol 4: 406-425.

36. Rahman KS, Rahman T, Lakshmanaperumalsamy P, Banat IM (2002) Occurrence of crude oil degrading bacteria in gasoline and diesel station soils. J Basic Microbiol 42: 284-291. 
Citation: Ismail W, Alhamad NA, El-Sayed WS, El Nayal AM, Yin-Ru C, et al. (2013) Bacterial Degradation of the Saturate Fraction of Arabian Light Crude oil: Biosurfactant Production and the Effect of ZnO Nanoparticles. J Pet Environ Biotechnol 4: 163. doi:10.4172/2157-7463.1000163

Page 11 of 11

37. Radwan SS, Al-Hasan RH, Ali N, Salamah S, Khanafer M (2005) Oil-consuming microbial consortia floating in the Arabian Gulf. Int Biodeter Biodegr 56: 28-33.

38. Zhang Z, Gai L, Hou Z, Yang C, Ma C, et al. (2010) Characterization and biotechnological potential of petroleum-degrading bacteria isolated from oilcontaminated soils. Bioresour Technol 101: 8452-8456.

39. Hassanshahian M, Ahmadinejad M, Tebyanian H, Kariminik A (2013) Isolation and characterization of alkane degrading bacteria from petroleum reservoir waste water in Iran (Kerman and Tehran provenances). Mar Pollut Bull 73: 300-305.

40. Mahjoubi M, Jaouani A, Guesmi A, Ben Amor S, Jouini A, et al. (2013) Hydrocarbonoclastic bacteria isolated from petroleum contaminated sites in Tunisia: isolation, identification and characterization of the biotechnological potential. N Biotechnol 30: 723-733.

41. Ali N, Dashti N, Al-Mailem D, Eliyas M, Radwan S (2012) Indigenous soil bacteria with the combined potential for hydrocarbon consumption and heavy metal resistance. Environ Sci Pollut Res Int 19: 812-820.

42. Al-Awadhi H, Sulaiman RH, Mahmoud HM, Radwan SS (2007) Alkaliphilic and halophilic hydrocarbon-utilizing bacteria from Kuwaiti coasts of the Arabian Gulf. Appl Microbiol Biotechnol 77: 183-186.

43. Radwan S, Mahmoud H, Khanafer M, Al-Habib A, Al-Hasan R (2010) Identities of epilithic hydrocarbon-utilizing diazotrophic bacteria from the Arabian Gulf Coasts, and their potential for oil bioremediation without nitrogen supplementation. Microb Ecol 60: 354-363.

44. Tanase AM, Ionescu R, Chiciudean L, Vassu T, Stoica I (2013) Characterization of hydrocarbon-degrading bacterial strains isolated from oil-polluted soil. Int Biodeter Biodegr 84: 150-154.

45. Warne Zoueki C, Ghoshal S, Tufenkji N (2010) Bacterial adhesion to hydrocarbons: role of asphaltenes and resins. Colloids Surf B Biointerfaces 79: 219-226.

46. Bredholt H, Josefsen K, Vatland A, Bruheim P, Eimhjellen K (1998) Emulsification of crude oil by an alkane-oxidizing Rhodococcus species isolated from seawater. Can J Microbiol 44: 330-340.

47. Obuekwe CO, Al-Jadi ZK, Al-Saleh ES (2009) Hydrocarbon degradation in relation to cell-surface hydrophobicity among bacterial hydrocarbon degraders from petroleum-contaminated Kuwait desert environment. Int Biodeter Biodegr 63: $273-279$

48. Wang XB, Chi CQ, Nie Y, Tang YQ, Tan Y, et al. (2011) Degradation of petroleum hydrocarbons (C6-C40) and crude oil by a novel Dietzia strain. Bioresour Technol 102: 7755-7761.

49. Al-Mailem DM, Sorkhoh NA, Al-Awadhi H, Eliyas M, Radwan SS (2010) Biodegradation of crude oil and pure hydrocarbons by extreme halophilic archaea from hypersaline coasts of the Arabian Gulf. Extremophiles 14: 321-328.
50. Giedraityte G, Kalediene L, Bubinas A (2001) Correlation between biosurfactant synthesis and microbial degradation of crude oil hydrocarbons. Ekologija (Vilnius) 3: 38-41.

51. Trindade PV, Sobral LG, Rizzo AC, Leite SG, Soriano AU (2005) Bioremediation of a weathered and a recently oil-contaminated soils from Brazil: a comparison study. Chemosphere 58: 515-522.

52. Zheng C, He J, Wang Y, Wang M, Huang Z (2011) Hydrocarbon degradation and bioemulsifier production by thermophilic Geobacillus pallidus strains. Bioresour Technol 102: 9155-9161.

53. Atlas RM (1991) Microbial hydrocarbon degradation-bioremediation of oil spills. J Chem Technol Biot 52: 149-156.

54. Palittapongarnpim M, Pokethitiyook P, Upatham ES, Tangbanluekal L (1998) Biodegradation of crude oil by soil microorganisms in the tropic. Biodegradation 9: 83-90.

55. Urum K, Grigson S, Pekdemir T, McMenamy S (2006) A comparison of the efficiency of different surfactants for removal of crude oil from contaminated soils. Chemosphere 62: 1403-1410.

56. Tilston EL, Collins CD, Mitchell GR, Princivalle J, Shaw LJ (2013) Nanoscale zerovalent iron alters soil bacterial community structure and inhibits chloroaromatic biodegradation potential in Aroclor 1242-contaminated soil Environ Pollut 173: 38-46.

57. Kuang Y, Zhou Y, Wang QP, Chen ZL (2012) [Effect of $\mathrm{Fe}$ and $\mathrm{Fe} / \mathrm{N}$ nanoparticles on the biodegradation of phenol by BFN at different $\mathrm{pH}$ values] Huan Jing Ke Xue 33: 3160-3166.

58. Karanth N, Deo P, Veenanadig N (1999) Microbial production of biosurfactants and their importance. Ferment Sci Technol 77: 116-126.

59. Rosenberg M, Kjellberg S (1985) Hydrophobic interactions in bacterial adhesion. Adv Microb Ecol 9: 353-393.

60. Nayak AS, Vijaykumar MH, Karegouder TB (2009) Characterization of biosurfactant produced by Pseudomonas sp. PNK-04 and its application in bioremediation. Int Biodeterior Biodegradation 63: 73-79.

61. Mulligan CN, Gibbs BF (1993) Factors influencing the economics of biosurfactants. Marcel Dekker Inc. New York 329-371.

62. Ismail W, Al-Rowaihi I, Al-Humam AA, Hamza R, El-Nayal A, et al. (2013) Characterization of a lipopeptide biosurfactant produced by a crude oilemulsifying Bacillus sp. Int Biodeterior and Biodegradation 84: 168-178.

63. Floodgate GD (1984) The fate of petroleum in marine ecosystems. Macmillan Publishing Company New York USA 355-398.

64. Zajic JE, Supplisson B, Volesky B (1974) Bacterial degradation and emulsification of No. 6 fuel oil. Environ Sci Technol 8: 664-668. 